\title{
Simplified detection of Mycobacterium tuberculosis in sputum using smear microscopy and PCR with molecular beacons
}

\section{Correspondence \\ Jaya Sivaswami Tyagi \\ jstyagi@aiims.ac.in}

Received 2 March 2007

Accepted 21 June 2007

\author{
Sagarika Haldar, ${ }^{1}$ Soumitesh Chakravorty, ${ }^{1} \dagger$ Manpreet Bhalla, ${ }^{2}$ \\ Shyamasree De Majumdar ${ }^{1}$ and Jaya Sivaswami Tyagi ${ }^{1}$ \\ ${ }^{1}$ Department of Biotechnology, All India Institute of Medical Sciences, Ansari Nagar, New Delhi \\ 110029, India \\ ${ }^{2}$ Lala Ram Sarup Institute of TB and Respiratory Diseases, New Delhi 110030, India
}

\begin{abstract}
The prompt diagnosis of smear-negative cases is a prerequisite to controlling tuberculosis (TB). Several new laboratory approaches, including nucleic acid amplification (NAA), are being evaluated in various disease settings to meet this challenge. However, NAA needs simplification before it is widely accepted. Furthermore, a supporting smear result improves confidence in and reliability of PCR. In this context, an asymmetric $\operatorname{dev} R$ PCR assay using two molecular beacon probes for visual or fluorimetric end-point detection of Mycobacterium tuberculosis was developed. The assays reproducibly detected $25 \mathrm{fg}$ M. tuberculosis DNA versus $100 \mathrm{fg}$ by conventional gel electrophoresis (henceforth referred to as gel assay). The devR and IS6110 PCR assays were blindly evaluated on sputum specimens obtained from a directly observed-treatment short-course centre. Universal sample processing (USP) smear microscopy and culture were used as a supportive test and the 'gold' standard, respectively. Among the 148 specimens analysed, 120 were M. tuberculosis culture-positive. Amongst the 122 direct smear-negative samples, 96 were culture-positive, of which 61 were detected by USP smear microscopy. All 35 USP smear-negative samples were positive by three or more PCR methods. $\operatorname{dev} R$ PCR had a sensitivity of $92.5 \%$ in the fluorimetric assay versus $86.7 \%$ by visual inspection and $90.8 \%$ by the gel method. IS6110 PCR performed at almost equivalent levels. devR visual and fluorimetric assays considered together yielded an increased sensitivity of $95 \%$ without compromising on a specificity of $92.9 \%$. The results suggest that the USP smear test is useful for diagnosing direct smear-negative TB and judiciously restricting PCR testing to only smear-negative samples. When used together, these tests can provide rapid diagnosis of smear-negative TB in a costeffective manner.
\end{abstract}

\section{INTRODUCTION}

Tuberculosis (TB) continues to be a leading cause of death with $\sim 2$ million casualties annually worldwide (WHO, 2005). Conventional approaches adopted for the diagnosis of TB include medical history, tuberculin skin test, chest $\mathrm{X}$-rays and bacteriological examination. The poor sensitivity of conventional smear microscopy and the delay in obtaining culture results prevent the early diagnosis of TB. We demonstrated the improved detection of direct

tPresent address: Division of Infectious Diseases, Department of Medicine and the Ruy V. Lourenço Center for the Study of Emerging and Reemerging Pathogens, New Jersey Medical School, University of Medicine and Dentistry of New Jersey, Newark, NJ 07103, USA.

Abbreviations: FAM, 6-carboxyfluorescein; ISBCN, IS6110 beacon; TB, tuberculosis; TO, target oligonucleotide; USP, universal sample processing. smear-negative cases by universal sample processing (USP) smear microscopy (Chakravorty \& Tyagi, 2005; Chakravorty et al., 2005a). However, a more sensitive test is required to detect samples with a low bacterial load. Since the advent of PCR, there has been an explosion in its use for TB diagnosis owing to its speed and sensitivity (Eisenach, 1998). However, these advantages are partially offset by economic and technical factors and simplification is required before PCR can be widely employed. In addition, PCR is often associated with some degree of false positivity (Beige et al., 1995). However, a positive smear result enhances the diagnostic accuracy of a positive PCR in the absence of culture (Haldar et al., 2005).

PCR products are most frequently detected by electrophoresis, which is cumbersome, time-consuming and carries a risk of cross-contamination. Alternatively, PCR products can be detected by molecular beacons that 
fluoresce upon hybridization to complementary target DNA thereby enabling rapid detection of pathogens. However, they have been mostly used in real-time formats (Tyagi \& Kramer, 1996; Tsourkas \& Bao, 2003). We have previously used devR PCR in gel assays for diagnosing pulmonary and extra-pulmonary TB (Singh et al., 1999, 2000; Chakravorty et al., 2005b, 2006). Against this background, we developed an asymmetric $\operatorname{dev} R$ PCR assay and used two 6-carboxyfluorescein (FAM)-labelled molecular beacons for end-point detection of Mycobacterium tuberculosis DNA in sputum. The $\operatorname{dev} R$ assay was compared with the molecular-beaconbased IS6110 PCR described previously (Piatek et al., 1998). USP smear microscopy and PCR results were analysed using culture as the 'gold' standard. The tests were found to be robust and the judicious use of PCR along with USP smears should find use in the rapid detection of smear-negative samples in high-TB-incidence settings.

\section{METHODS}

Clinical specimens. Sputum samples $(n=148)$ were collected from subjects attending the directly-observed-treatment short-course (DOTS) centre at the Lala Ram Sarup Institute of TB and Respiratory Diseases (LRS) and included $120 \mathrm{M}$. tuberculosis culture-positive and 28 culture-negative samples (retrospectively determined). Under the DOTS strategy, only subjects who are classified positive by direct smear test are given anti-tubercular therapy. Consequently, smear-negative TB cases are not treated. In this study, an effort was made to collect samples that were either direct smear-negative or with a low bacterial load. In this way, we could assess the role of USP smear microscopy and PCR in rapidly detecting direct-smear-negative TB in samples whose culture status was established only $2-4$ weeks thereafter. Sputum portions remaining after routine smear microscopy testing were collected before antitubercular treatment was initiated at the DOTS centre. All samples were stored at $4{ }^{\circ} \mathrm{C}$ within $5-6 \mathrm{~h}$ of collection and processed within the next 6-36 h.
Specimen processing. Aliquots of USP-processed samples were analysed by smear microscopy, culture and PCR as described previously (Chakravorty \& Tyagi, 2005; Chakravorty et al., 2005a). Briefly, 1.5-2 vols USP solution [6 $\mathrm{M}$ guanidinium hydrochloride, $50 \mathrm{mM}$ Tris/Cl (pH 7.5), $25 \mathrm{mM}$ EDTA, $0.5 \%$ Sarcosyl, $0.1 \mathrm{M} \beta$ mercaptoethanol (all from Sigma)] was added to each sputum sample. After incubation for 5-10 $\mathrm{min}$ at room temperature (or $15 \mathrm{~min}$ at $37{ }^{\circ} \mathrm{C}$ if the sample was extremely viscous), $10-15 \mathrm{ml}$ sterile water was added and the sample was centrifuged at 5000-6000 $\mathrm{g}$ for 15-20 min at room temperature. The supernatant was discarded carefully and the sediment was washed once more with $2 \mathrm{ml}$ USP solution and recentrifuged as before. The pellet was washed thoroughly with $10 \mathrm{ml}$ water, resuspended in $500 \mu \mathrm{l} 0.05 \%$ Tween 80 and used for smear microscopy $(20 \%)$, culture $(40 \%)$ and DNA isolation and PCR $(40 \%)$.

The slides were subjected to Ziehl-Neelsen staining and graded by two independent readers as described previously (Akhtar et al., 2000). USPprocessed deposits were inoculated in 7H9 liquid media containing albumin dextrose complex and PANTA (polymyxin B, amphotericin B, nalidixic acid, trimethoprim and azlocillin) supplement (Becton Dickinson) to maximize the isolation of bacteria from smear-negative samples. The tubes were incubated at $37^{\circ} \mathrm{C}$ for up to 4 weeks. USP has been shown previously to be compatible with solid and liquid culture media and was no more toxic than $\mathrm{N}$-acetyl-L-cysteine (NALC) $-\mathrm{NaOH}$ (Chakravorty \& Tyagi, 2005). The cultures were confirmed by $M$. tuberculosis complex-specific devR PCR (Chakravorty et al., 2006). A definite TB diagnosis was made with a positive culture from sputum. DNA was isolated from the remaining $200 \mu \mathrm{l}$ portion of the sample as described previously (Chakravorty \& Tyagi, 2005). Briefly, $120 \mu$ lysis solution containing $10 \%$ Chelex-100 (Bio-Rad Laboratories), $0.3 \%$ Tween 20 and $0.03 \%$ Triton X-100 (both from Sigma) was added to the processed sediment, mixed well and incubated at $90{ }^{\circ} \mathrm{C}$ for $40 \mathrm{~min}$. The lysate was centrifuged briefly at 12000 r.p.m. for $10 \mathrm{~min}$ and used in PCR.

Design and characterization of the molecular beacons. MB 1 and MB 2 molecular beacon oligonucleotide probes (Metabion) mapped within the M. tuberculosis devR gene (Table 1). The annealing temperature for PCR was determined from the denaturation profiles of the molecular beacons as described by Tyagi \& Kramer (1996).

Table 1. Sequences of the primers and molecular beacon probes used in the study

\begin{tabular}{|c|c|c|c|c|}
\hline $\begin{array}{l}\text { Primer/molecular } \\
\text { beacon }\end{array}$ & Sequence $\left(5^{\prime}-3^{\prime}\right)$ & Target gene, detection format & Size of PCR product & Reference \\
\hline $\operatorname{devRf} 4^{*}$ & CCGATCTGCGCTGTCTGATC & $\operatorname{dev} R$, fluorescence-based, gel-based & $144 \mathrm{bp}$ & This study \\
\hline $\operatorname{devRr} 3^{*}$ & GTCCAGCGCCCACATCTTT & & & \\
\hline ISBCNF & CTAACCGGCTGTGGGTAG & IS6110, fluorescence-based, gel-based & $200 \mathrm{bp}$ & Piatek et al. (1998) \\
\hline ISBCNR & GTCTTTCAGGTCGAGTAC & & & \\
\hline MB $1 \dagger$ & $\begin{array}{l}\text { FAM-GGCCGTAAAGACATCAAGG- } \\
\text { GAATGGAACGGCC-DABCYL }\end{array}$ & $\operatorname{dev} R$, fluorescence-based & - & This study \\
\hline MB $2 \ddagger$ & $\begin{array}{l}\text { FAM-GGCC } \overline{\text { GTTCACGTCCTACAC- }} \\
\text { CTCTACGGCC-DABCYL }\end{array}$ & $\operatorname{dev} R$, fluorescence-based & - & This study \\
\hline TO 1 & TCCATTCCCTTGATGTCTTT & $\operatorname{dev} R$, fluorescence-based & - & This study \\
\hline TO 2 & AGAGGTGTAGGACGTGA & & - & This study \\
\hline ISBCN & $\begin{array}{l}\text { FAM-GCACCGAGGTGGCCATCGTG- } \\
\text { GAAGCGGGTGC-DABCYL }\end{array}$ & IS6110, fluorescence-based & - & Piatek et al. (1998) \\
\hline IS6110 TO & GCTTCCACGATGGCCACCT & IS6110, fluorescence-based & - & This study \\
\hline
\end{tabular}

*devRf4 and devRr3 amplified a region mapping between M. tuberculosis genome coordinates 3499551 and 3499694 .

$\dagger$ \B 1, M. tuberculosis genome coordinates 3 499586-3 499605.

¥MB 2, M. tuberculosis genome coordinates $3499657-3499673$. 
Briefly, the change in fluorescence of MB 1, MB 2 or the IS6110 beacon (ISBCN) either present alone or with the corresponding complementary target oligonucleotide (TO) over a temperature range was measured in the I-Cycler (Bio-Rad). For this, two tubes containing $0.3 \mu \mathrm{M}$ each of MB 1 and MB 2 or ISBCN in $50 \mu \mathrm{l}$ buffer (3.5 mM MgCl 2 and $10 \mathrm{mM}$ Tris/ $\mathrm{HCl}, \mathrm{pH} 8.0$ ) and $0.3 \mu \mathrm{M}$ each of MB 1 and MB 2 plus $0.6 \mu \mathrm{M} \operatorname{devR}$ TO 1 and TO 2 or IS6110 TO were subjected to a decrease in temperature from $96{ }^{\circ} \mathrm{C}$ to $41{ }^{\circ} \mathrm{C}$ in $1{ }^{\circ} \mathrm{C}$ steps and fluorescence was measured during a $30 \mathrm{~s}$ hold at each temperature. The melting curve of the molecular beacons was obtained from a $-\mathrm{d} F / \mathrm{d} T$ plot. The signal to noise ratio of $\mathrm{MB} 1$, MB 2 and $\mathrm{MB} 1+\mathrm{MB} 2$ was determined by measuring the fluorescence intensity of the molecular beacon in the presence or absence of a twofold excess of its corresponding TO at $43{ }^{\circ} \mathrm{C}$ (Fig. 1).

PCR assays. Six PCR assays were performed on each sputum sample. The $\operatorname{dev} R$-specific primers were designed to amplify a short segment of DNA (144 bp) for efficient annealing with the molecular beacons. The details of primers and the sizes of the PCR amplification products are given in Table 1. Three detection formats were employed: molecular-beacon-based end-point detection using fluorimetric and visual methods (methods 1 and 2, respectively) and gel detection using ethidium bromide (method 3 ).

For $\operatorname{devR}$ assays (methods 1 and 2), the reactions contained $0.1 \mu \mathrm{M}$ devRf4 primer, $0.5 \mu \mathrm{M}$ devRr3 primer (Microsynth), $1 \times$ PCR buffer (100 mM Tris/HCl, pH 8.8, $500 \mathrm{mM} \mathrm{KCl,} 0.8 \%$ Nonidet $\mathrm{P} 40$ ),

(a)

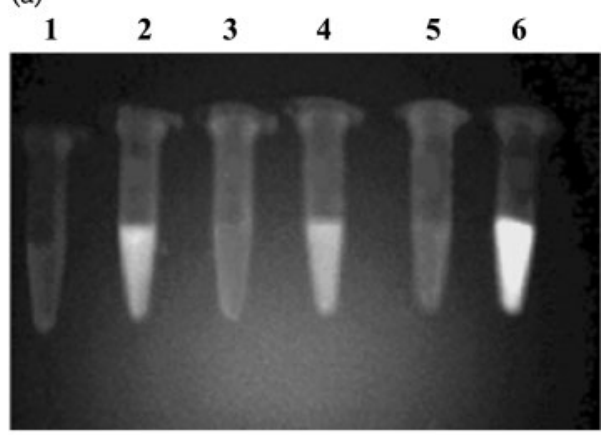

Visual

(b)

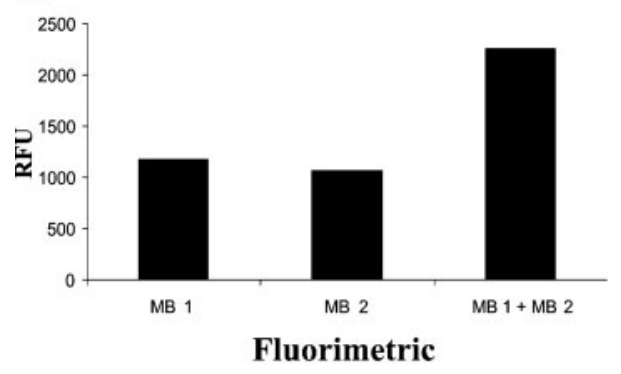

Fig. 1. Signal to noise ratio of molecular beacons. The signal to noise ratio of MB 1, MB 2 and MB $1+$ MB 2 was determined by measuring the beacon fluorescence intensity in the presence of a twofold excess of its corresponding $\mathrm{TO}$ at $43{ }^{\circ} \mathrm{C}$. (a) Tubes: $1, \mathrm{MB}$ $1 ; 2$, MB 1+TO 1; 3, MB 2; 4, MB 2+TO 2; 5, MB 1+ MB 2; 6, MB $1+\mathrm{MB} 2+\mathrm{TO} 1+\mathrm{TO} 2$. (b) Relative fluorescence (RFU) of reactions containing the molecular beacons indicated in the presence of their corresponding TOs.
$4 \mathrm{mM} \mathrm{MgCl}_{2}, \quad 0.25 \mathrm{mM}$ dNTPs, $2.5 \mathrm{U}$ Taq DNA polymerase (GeneTaq; MBI Fermentas), $10 \mu \mathrm{l}$ specimen DNA and $0.3 \mu \mathrm{M}$ and $0.6 \mu \mathrm{M}$ each of MB 1 and MB 2 for methods 1 and 2, respectively. For the $\operatorname{dev} R$ assay (method 3), reactions contained $0.5 \mu \mathrm{M}$ each of primers devRf4 and devRr3, $1 \times$ PCR buffer, $1.5 \mathrm{mM} \mathrm{MgCl}_{2}, 0.2 \mathrm{mM}$ dNTPs, $1 \mathrm{U}$ Taq DNA polymerase and $10 \mu \mathrm{l}$ specimen DNA. The thermal cycling parameters were $10 \mathrm{~min}$ at $94{ }^{\circ} \mathrm{C}, 45$ cycles each of $1 \mathrm{~min}$ at $94{ }^{\circ} \mathrm{C}, 1 \mathrm{~min}$ at $43{ }^{\circ} \mathrm{C}$ and $30 \mathrm{~s}$ at $72{ }^{\circ} \mathrm{C}$ and a final extension of $7 \mathrm{~min}$ at $72{ }^{\circ} \mathrm{C}$. For methods 1 and 2, this was followed by a final denaturation $\left(94{ }^{\circ} \mathrm{C}\right.$ for $\left.5 \mathrm{~min}\right)$ and annealing $\left(43{ }^{\circ} \mathrm{C}\right.$ for $10 \mathrm{~min})$.

For IS6110 assays (methods 1 and 2), the reactions contained $0.1 \mu \mathrm{M}$ IS6110 forward primer, $0.5 \mu \mathrm{M}$ IS6110 reverse primer (herein referred to as ISBCNF and ISBCNR primers), $1 \times$ PCR buffer, $4 \mathrm{mM} \mathrm{MgCl}_{2}$, $0.25 \mathrm{mM}$ dNTPs, $2.5 \mathrm{U}$ Taq DNA polymerase, $10 \mu \mathrm{l}$ specimen DNA and $0.3 \mu \mathrm{M}$ and $0.6 \mu \mathrm{M}$ ISBCN for methods 1 and 2, respectively. IS6110 assay (method 3) reactions contained $0.5 \mu \mathrm{M}$ each of primers ISBCNF and ISBCNR (Piatek et al., 1998), $1 \times$ PCR buffer, $1.5 \mathrm{mM}$ $\mathrm{MgCl}_{2}, 0.2 \mathrm{mM}$ dNTPs, $1 \mathrm{U}$ Taq DNA polymerase and $10 \mu \mathrm{l}$ specimen DNA. The thermal cycling parameters were $10 \mathrm{~min}$ at $94{ }^{\circ} \mathrm{C}, 45$ cycles each of $1 \mathrm{~min}$ at $94{ }^{\circ} \mathrm{C}, 1 \mathrm{~min}$ at $60{ }^{\circ} \mathrm{C}$ and $30 \mathrm{~s}$ at $72{ }^{\circ} \mathrm{C}$, and a final extension of $7 \mathrm{~min}$ at $72{ }^{\circ} \mathrm{C}$. For methods 1 and 2 , this was followed by a final denaturation $\left(94{ }^{\circ} \mathrm{C}\right.$ for $5 \mathrm{~min}$ ) and annealing $\left(60{ }^{\circ} \mathrm{C}\right.$ for $\left.10 \mathrm{~min}\right)$.

Detection of amplified products. In method 1 (fluorimetric format), the reaction contents were transferred into wells of a 96well plate containing $150 \mu \mathrm{l} 20 \mathrm{mM}$ Tris/Cl $(\mathrm{pH} \mathrm{8.0)}$ and $1 \mathrm{mM}$ $\mathrm{MgCl}_{2}$ and the fluorescence was measured using $491 \mathrm{~nm}$ excitation and $515 \mathrm{~nm}$ emission in a spectrofluorimeter (Spectra MAX Gemini XS; Molecular Devices) at $43{ }^{\circ} \mathrm{C}$. In method 2 (visual format), the tubes were placed over a blue light source (Dark Reader; Clare Chemical Research) for detection of fluorescence by visual inspection by two persons. In method 3 (gel format), the PCR products were detected by ethidium bromide staining after electrophoresis on a $2.3 \%$ agarose gel and illumination with UV light.

Performance of the devR PCR assay. The limit of detection was evaluated on serial dilutions of purified M. tuberculosis DNA. PCR assays were set up as described above in fluorimetric, visual and gel formats. The specificity of the $\operatorname{devR}$ PCR assay was assessed using DNA in crude lysates prepared from scrapings of mycobacterial cultures grown on Löwenstein-Jensen slants by heating in $0.1 \%$ Triton X-100 for $40 \mathrm{~min}$ at $90{ }^{\circ} \mathrm{C}$.

Statistical analysis. The diagnostic performance of PCR was evaluated using culture as the 'gold' standard. Test results were classified as true positives (Tp), true negatives ( $\mathrm{Tn}$ ), false positives (Fp) and false negatives (Fn). Sensitivity was calculated as $[\mathrm{Tp} /(\mathrm{Tp}$ $+\mathrm{Fn})] \times 100$ and specificity as $[\operatorname{Tn} /(\operatorname{Tn}+\mathrm{Fp})] \times 100$. The efficiency was calculated as $[\mathrm{Tp}+\mathrm{Tn} / N] \times 100$, where $N=148$. The statistical parameter $\mathrm{Z}$ factor was used to evaluate the quality of the fluorimetric assay (Zhang et al., 1999). The significance of the difference between direct and USP smear results was calculated using McNemar's test (Altman, 1991). The performance of various detection techniques was assessed for agreement between them by calculating the kappa agreement value (Altman, 1991).

\section{RESULTS AND DISCUSSION}

This study was designed to assess a sensitive smear microscopy technique and simplified PCR test for diagnosing smear-negative TB. USP methodology was used to process samples $(n=148)$ since portions of the same 
processed sediment could be used for smear microscopy, culture and PCR. USP smear microscopy was performed as it is highly sensitive and can support PCR findings (Chakravorty et al., 2005a; Haldar et al., 2005). Culture was used as the 'gold' standard to evaluate USP smear microscopy and PCR performance.

\section{Improved detection by USP smear microscopy}

A sensitive smear test is an extremely handy and low-cost tool for diagnosing TB in endemic disease settings. The USP smear technique was expected to detect additional positive samples over and above those detected by direct smear examination. One hundred and twenty of 148 samples were positive by liquid culture. Eighty-five of 120 culture-positive samples were USP smear-positive in contrast to only 24 that were positive by direct smear examination, and not a single direct smear-positive sample was missed. USP smears could detect 61 more samples as positive than the direct smear technique. Thus direct smear microscopy had a sensitivity of only $20 \%$ versus USP smear, which had a sensitivity of $\sim 71 \%$ (Table $2 ; P$ $<0.0001)$. These samples were predominantly of scanty grade and their detection is consistent with the enhanced performance of USP smear microscopy (Chakravorty et al., 2005a). We cannot explain why two USP smear-positive samples failed to grow in culture and yet were positive according to all six PCR assays.

\section{Evaluation of PCR assays and molecular beacons}

From the thermal denaturation profiles of MB 1 and MB 2, $43{ }^{\circ} \mathrm{C}$ was determined to be the optimum annealing temperature for PCR (not shown). The use of asymmetric PCR and two molecular beacons (vs one molecular beacon) improved the signal intensity by over twofold both visually and fluorimetrically (Fig. 1). This was attributed to the preferential accumulation of the target DNA strand during asymmetric amplification.

\section{Performance of PCR assays}

The $\operatorname{dev} R$ PCR assay was judged to be quite specific for $M$. tuberculosis complex organisms. DNA from both $M$. tuberculosis and Mycobacterium bovis was detected and in silico analysis indicated that $\operatorname{dev} R$ is completely conserved in Mycobacterium africanum and Mycobacterium microti (http:// www.sanger.ac.uk/sequencing/Mycobacterium/africanum/; http://www.sanger.ac.uk/Projects/M_microti/). The assay could not distinguish between the $M$. tuberculosis complex and Mycobacterium kansasii DNA (not shown). However, M. tuberculosis can be readily verified by IS6110 PCR, which does not detect M. kansasii (Hellyer et al., 1996). It should be mentioned that $M$. tuberculosis lacking IS6110 and $M$. kansasii cannot be discriminated by these two assays since they are both positive for the $\operatorname{devR}$ assay and negative for IS6110 PCR. However, the detection of M. kansasii by the $\operatorname{dev} R$ assay was not considered to be a serious concern as the

Table 2. Results of smear and PCR tests on sputum

\begin{tabular}{|c|c|c|c|c|c|c|}
\hline \multirow[t]{2}{*}{ Test } & \multirow[t]{2}{*}{ Result } & \multicolumn{2}{|c|}{ Culture } & \multirow{2}{*}{$\begin{array}{c}\text { Sensitivity } \\
(\%)\end{array}$} & \multirow{2}{*}{$\begin{array}{c}\text { Specificity } \\
(\%)\end{array}$} & \multirow{2}{*}{$\begin{array}{c}\text { Efficiency } \\
(\%)\end{array}$} \\
\hline & & Positive & Negative & & & \\
\hline \multirow[t]{2}{*}{ Direct smear } & Positive & 24 & 2 & 20.0 & 92.9 & 33.8 \\
\hline & Negative & 96 & 26 & & & \\
\hline \multirow[t]{2}{*}{ USP smear } & Positive & 85 & 2 & 70.8 & 92.9 & 75.0 \\
\hline & Negative & 35 & 26 & & & \\
\hline \multicolumn{7}{|l|}{$\operatorname{devR}$ PCR } \\
\hline \multirow{2}{*}{ Fluorimetric assay } & Positive & 111 & 2 & 92.5 & 92.9 & 92.6 \\
\hline & Negative & 9 & 26 & & & \\
\hline \multirow[t]{2}{*}{ Visual assay } & Positive & 104 & 2 & 86.7 & 92.9 & 87.8 \\
\hline & Negative & 16 & 26 & & & \\
\hline \multirow[t]{2}{*}{ Gel assay } & Positive & 109 & 5 & 90.8 & 82.1 & 89.2 \\
\hline & Negative & 11 & 23 & & & \\
\hline \multicolumn{7}{|l|}{ IS6110 PCR } \\
\hline \multirow[t]{2}{*}{ Fluorimetric assay } & Positive & 110 & 4 & 91.7 & 85.7 & 90.5 \\
\hline & Negative & 10 & 24 & & & \\
\hline \multirow[t]{2}{*}{ Visual assay } & Positive & 106 & 5 & 88.3 & 82.1 & 87.1 \\
\hline & Negative & 14 & 23 & & & \\
\hline \multirow[t]{2}{*}{ Gel assay } & Positive & 102 & 3 & 85.0 & 89.3 & 85.8 \\
\hline & Negative & 18 & 25 & & & \\
\hline \multirow[t]{2}{*}{ Combined assay ${ }^{\star}$} & Positive & 114 & 2 & 95.0 & 92.9 & 94.6 \\
\hline & Negative & 6 & 26 & & & \\
\hline Total $(n=148)$ & & 120 & 28 & & & \\
\hline
\end{tabular}

${ }^{\star}$ A sample was considered to be positive when it was positive by both $\operatorname{dev} R$ beacon-based assays. 
yield of mycobacteria other than tubercle (MOTT) bacilli from clinically suspected cases is negligible in India (Katoch, 2004). In our own experience too, MOTT bacilli were not isolated while handling over 2000 cultures.

To determine the limit of detection of M. tuberculosis DNA, serial DNA dilutions ranging from $500 \mathrm{ng}$ to $10 \mathrm{fg}$ were added to $\operatorname{dev} R$ PCR reactions. By the gel assay, up to $100 \mathrm{fg}$ DNA was detected. The fluorimetric and the visual methods were somewhat more sensitive and could detect 25 fg DNA (Fig. 2). When MB 1 and MB 2 were used together, the $\operatorname{dev} R$ assay was as sensitive as the multicopy IS6110 assay (Fig. 2a). The $\mathrm{Z}$ factor was used to evaluate the fluorimetric assays (Zhang et al., 1999); values of 0.65 and 0.7 were obtained for $\operatorname{dev} R$ and IS6110 assays, respectively, indicating that these assays were of good quality.

\section{Evaluation of molecular beacons for TB detection}

In the fluorimetric assays, a PCR test was considered to be positive when the relative fluorescence units obtained with a test sample were more than the mean relative fluorescence units of the DNA-negative controls $+3 \mathrm{SD}$. In the visual assays, a PCR was scored as positive when the end-point fluorescence intensity appeared to be more than that of control tubes lacking DNA (Fig. 2b). In this study, although USP smears had a definite utility, in that they were positive in 85 culture-positive samples versus 24 that were positive by direct smear examination, 35 culturepositive samples were still missed by the USP smear test (Table 2). All these 35 samples were detected by at least three PCR assays, indicating that PCR has a role in the rapid diagnosis of smear-negative $\mathrm{TB}$.

Using culture as the 'gold' standard, devR assay sensitivity was $92.5 \%, 86.7 \%$ and $90.8 \%$ for the fluorimetric, visual and gel detection formats, respectively. The cutoff was apparently set higher for a positive for the fluorimetric assay than for the visual assay, yet the specificities of the $\operatorname{dev} R$ fluorimetric and visual assays were equal (92.9\%). Perhaps this highlights that the very small numbers of false-positive PCR results did not permit a significant comparison of the specificities of these two assays. The sensitivity of the IS6110 assay, in particular that of the fluorescence-based formats, was comparable at $91.7 \%$, $88.3 \%$ and $85 \%$ for the fluorimetric, visual and gel detection formats, respectively. The efficiency of all the assays ranged between $85.8 \%$ and $92.6 \%$ (Table 2).

The various detection formats were compared using the kappa agreement test whereby values between 0.6 and 0.8 indicate good agreement between any two tests (Altman, 1991). The $\operatorname{dev} R$ visual and fluorimetric assays had kappa values of 0.72 and 0.75 , respectively, in comparison to the gel assay. Likewise, the IS6110 visual and fluorimetric assays had kappa values of 0.79 and 0.74 respectively, in comparison to the gel assay. The fluorescence-based assays also had good agreement amongst themselves: a value of 0.77 for both $\operatorname{devR}$ and IS6110 assays. On the basis of the (a)

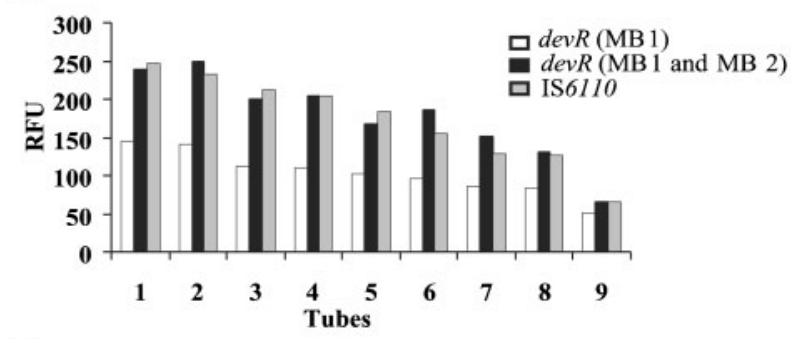

(b)

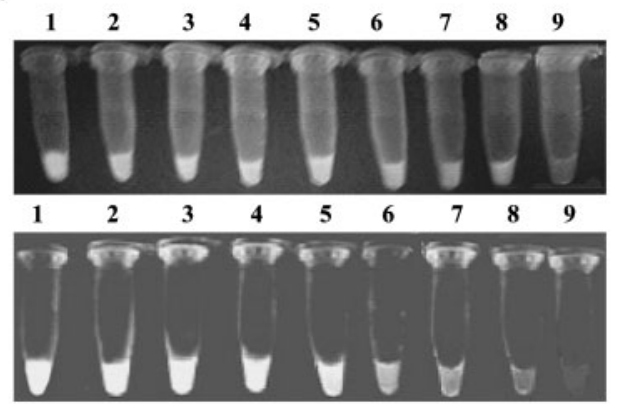

$\operatorname{dev} R$

(MB 1 + MB 2)

(c)

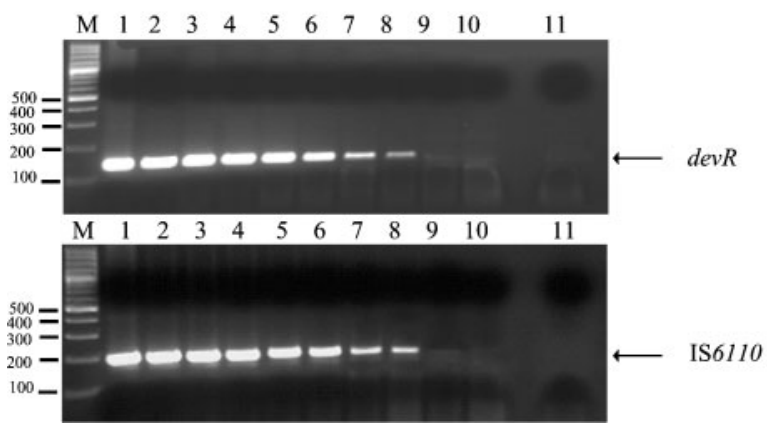

Fig. 2. Limit of detection by $\operatorname{dev} R$ and IS6110 PCR assays for the three detection formats (a, fluorimetric; b, visual; c, gel). Serial dilutions of $M$. tuberculosis DNA were added as listed below. $(a, b)$ Columns/tubes: 1, $250 \mathrm{ng} ; 2,25 \mathrm{ng} ; 3,2.5 \mathrm{ng} ; 4,250 \mathrm{pg} ; 5$, 25 pg; 6, 2.5 pg; 7, 250 fg; 8, 25 fg; 9, DNA negative control. (c) Lanes: M, 100 bp DNA ladder; 1, 250 ng; 2, 25 ng; 3, 2.5 ng; 4, 250 pg; 5, 25 pg; 6, 2.5 pg; 7, 250 fg; 8, 100 fg; 9, 25 fg; 10, $10 \mathrm{fg} ; 11$, DNA negative control.

kappa agreement test results $(P<0.0001)$, we conclude that end-point detection with fluorescent probes performed well in comparison to the conventional gel assay; in fact the fluorimetric format surpassed the gel assay in its performance.

Among the 120 culture-positive samples that were analysed, 35 samples were missed by one or more PCR assays (false-negative). Of these, 29 samples were either negative or had low bacterial loads as determined by USP smears. PCR false-negative samples included five cases that were missed by all six PCR assays. Regarding false-positive PCR results (7\%), two samples were positive in all six PCR 
assays, one sample was positive in all three IS6110 assays and the $\operatorname{dev} R$ gel assay, two samples were positive in the $\operatorname{dev} R$ gel assay and IS6110 visual assay and one sample was positive in only the IS6110 fluorimetric assay. One culturepositive sample was negative by IS6110 PCR but detected by devR PCR. The absence of IS6110 sequences in this particular M. tuberculosis isolate was established by PCR. The isolation of M. tuberculosis strains from India that lack IS6110 has been reported (Narayanan et al., 2001; Radhakrishnan et al., 2001) and our findings underline the utility of $\operatorname{dev} R$ PCR in detecting IS6110-negative organisms.

Amongst the beacon-based assays, $\operatorname{devR}$ PCR was as sensitive as the multicopy target IS6110 PCR without compromising on specificity. This is ascribed to the use of two beacons in the $\operatorname{dev} R$ asymmetric assay versus one beacon in the IS6110 assay. Molecular beacons have been used for determining drug resistance among cultured $M$. tuberculosis isolates (Piatek et al., 1998) and also for $M$. tuberculosis detection in sputum (Li et al., 2000). The majority of assays for pathogen detection use molecular beacons in automated real-time formats. These technologies would be out of reach in settings where they are most required. In this study, DNA amplification was conveniently carried out in a regular thermal cycler and the products were detected at the end point using molecular beacons in either the visual or fluorimetric formats. The advantages of the closed-tube visual assay are quite obvious as it avoids handling of tubes after PCR and thus minimizes cross-contamination between samples. However, the efficiency of the visual assays was somewhat lower than that of the fluorimetric assays.

The importance of detecting smear-negative TB cannot be overemphasized; up to half of the new $\mathrm{TB}$ cases are reportedly smear-negative (Bennedsen et al., 1996), which leads to delays in the institution of therapy, increased transmission from undetected infectious cases and associated increased medical costs. In this study, USP smear microscopy detected an additional $\sim 51 \%$ of the culturepositive samples compared to direct smear (Table 2). PCR was able to detect all culture-positive samples that were missed by the USP smear. The results of various combinations of PCR assays were analysed and the highest efficiency $(94.6 \%)$ was noted when the $\operatorname{dev} R$ visual and fluorimetric assays were considered together (Table 2).

In conclusion, we have demonstrated the feasibility of using molecular beacons in simplified formats for $\mathrm{TB}$ diagnosis. To the best of our knowledge, this is the first report that uses two molecular beacons in combination with asymmetric PCR to increase the sensitivity of the endpoint fluorescence assay. We believe that the assay performance can be further improved by use of dUTP and uracil glycosylase, the use of molecular beacons with a higher fluorescence ratio in the presence of the target sequence and by digital capture of the fluorescence. When used in conjunction with the low-cost USP smear test, the beacon-based assays promise to accurately and rapidly diagnose smear-negative TB. However, with a specificity of $93 \%$ and a false-positive rate of $7 \%$, PCR results should be interpreted in the context of clinical presentation, especially in low-incidence areas.

\section{ACKNOWLEDGEMENTS}

S. H. thanks the Department of Biotechnology, Government of India (DBT), for a stipend during her Masters in Biotechnology and for a JRF during her doctoral studies, S. C. thanks the DBT for a Senior Research Fellowship, M. B. thanks the World Health Organization for a fellowship, and S.D.M. thanks the CSIR for a Junior Research Fellowship. Project funding to J.S. T. from the DBT is acknowledged. Dr M. Kumar, MD is sincerely acknowledged for reading and grading the smear slides. Technical assistance from Mr Sanjay Kumar and Ms Alka Pawar and expert assistance with the statistical analysis from Ms M. Kalaivani are duly acknowledged.

\section{REFERENCES}

Akhtar, M., Bretzel, G., Boulahbal, F., Dawson, D., Fattorini, L., Feldmann, K., Frieden, T., Havelková, M., de Kantor, I. N. \& other authors (2000). Technical Guide: Sputum Examination For Tuberculosis by Direct Microscopy in Low Income Countries, 5th edn. Paris: International Union Against Tuberculosis and Lung Disease.

Altman, D. G. (1991). Some common problems in medical research. In Practical Statistics for Medical Research, pp. 396-439. London: Chapman \& Hall.

Beige, J., Lokies, J., Schaberg, T., Finckh, U., Fischer, M., Mauch, H., Lode, H., Kohler, B. \& Rolfs, A. (1995). Clinical evaluation of a Mycobacterium tuberculosis PCR assay. J Clin Microbiol 33, 90-95.

Bennedsen, J., Thomsen, V. O., Pfyffer, G. E., Funke, G., Feldmann, K., Beneke, A., Jenkins, P. A., Hegginbothom, M., Fahr, A. \& other authors (1996). Utility of PCR in diagnosing pulmonary tuberculosis. J Clin Microbiol 34, 1407-1411.

Chakravorty, S. \& Tyagi, J. S. (2005). Novel multipurpose methodology for detection of mycobacteria in pulmonary and extrapulmonary specimens by smear microscopy, culture, and PCR. J Clin Microbiol 43, 2697-2702.

Chakravorty, S., Dudeja, M., Hanif, M. \& Tyagi, J. S. (2005a). Utility of USP smear microscopy, culture and PCR in the diagnosis of pulmonary tuberculosis. J Clin Microbiol 43, 2703-2708.

Chakravorty, S., Sen, M. K. \& Tyagi, J. S. (2005b). Diagnosis of extrapulmonary tuberculosis by smear, culture and PCR using universal sample processing technology. J Clin Microbiol 43, 4357-4362.

Chakravorty, S., Pathak, D., Dudeja, M., Haldar, S., Hanif, M. \& Tyagi, J. S. (2006). PCR amplification of shorter fragments from the devR $(R v 3133 c)$ gene significantly increases the sensitivity of tuberculosis diagnosis. FEMS Microbiol Lett 257, 306-311.

Eisenach, K. D. (1998). Molecular diagnostics. In Mycobacterium: Molecular Biology and Virulence, pp. 161-179. Edited by C. Ratledge \& J. Dale. Oxford: Blackwell Science.

Haldar, S., De Majumdar, S., Chakravorty, S., Tyagi, J. S., Bhalla, M. \& Sen, M. K. (2005). Detection of acid-fast bacilli in postlysis debris of clinical specimens improves the reliability of PCR. J Clin Microbiol 43, 3580-3581.

Hellyer, T. J., DesJardin, L. E., Assaf, M. K., Bates, J. H., Cave, M. D. \& Eisenach, K. D. (1996). Specificity of IS6110-based amplification assays for Mycobacterium tuberculosis complex. J Clin Microbiol 34, 2843-2846. 
Katoch, V. M. (2004). Infections due to non-tuberculous mycobacteria (NTM). Indian J Med Res 120, 290-304.

Li, Q.-G., Liang, J.-X., Luan, G.-Y., Zhang, Y. \& Wang, K. (2000). Molecular beacon-based homogeneous fluorescence PCR assay for the diagnosis of infectious diseases. Anal Sci 16, 245-248.

Narayanan, S., Parandaman, V., Narayanan, P. R., Venkatesan, P., Girish, C., Mahadevan, S. \& Rajajee, S. (2001). Evaluation of PCR using TRC(4) and IS6110 primers in detection of tuberculous meningitis. J Clin Microbiol 39, 2006-2008.

Piatek, A. S., Tyagi, S., Pol, A. C., Telenti, A., Miller, L. P., Kramer, F. R. \& Alland, D. (1998). Molecular beacon sequence analysis for detecting drug resistance in Mycobacterium tuberculosis. Nat Biotechnol 16, 359-363.

Radhakrishnan, I., Manju, Y. K., Kumar, R. A. \& Mundayoor, S. (2001). Implications of low frequency of IS6110 in fingerprinting field isolates of Mycobacterium tuberculosis from Kerala, India. J Clin Microbiol 39, 1683.
Singh, K. K., Nair, M. D., Radhakrishnan, K. \& Tyagi, J. S. (1999). Utility of PCR assay in diagnosis of en-plaque tuberculoma of the brain. J Clin Microbiol 37, 467-470.

Singh, K. K., Muralidhar, M., Kumar, A., Chattopadhyaya, T. K., Kapila, K., Singh, M. K., Sharma, S. K., Jain, N. K. \& Tyagi, J. S. (2000). Comparison of in house polymerase chain reaction with conventional techniques for the detection of Mycobacterium tuberculosis DNA in granulomatous lymphadenopathy. J Clin Pathol 53, 355-361.

Tsourkas, A. \& Bao, G. (2003). Shedding light on health and disease using molecular beacons. Brief Funct Genomic Proteomic 1, 372-384.

Tyagi, S. \& Kramer, F. R. (1996). Molecular beacons: probes that fluoresce upon hybridization. Nat Biotechnol 14, 303-308.

WHO (2005). Global Tuberculosis Control Surveillance, Planning, Financing. Geneva: World Health Organization.

Zhang, J. H., Chung, T. D. \& Oldenburg, K. R. (1999). A simple statistical parameter for use in evaluation and validation of high throughput screening assays. J Biomol Screen 4, 67-73. 